\title{
New Record of Columbarium pagoda pagoda (Lesson, 1834, Gastropoda, Turbinellidae) in Korean water
}

\author{
Yong Seok Lee and Jun-Sang Lee ${ }^{1}$ \\ Department of Parasitology, College of Medicine and UHRC, Inje University, Busan, 614-735, Korea \\ ${ }^{1}$ Institute of Environmental Research, Kangwon National University, Chunchon 200-701
}

\section{ABSTRACT}

The Turbinellidae shell Columbarium pagoda pagoda (Lesson, 1834), from the southern coast of Korea was recorded as new to the Korean molluscan fauna. The shell is typically solid and fusiform, with a well elongated spire and long anterior canal, and keel with a row developed spine. The protoconch is small, planorboid to depressed dome-shaped. The family Turbinellidae is reported from Korea for the first time.

Key words: Columbarium pagoda pagoda, Turbinellidae, new record, Korean water

\section{INTRODUCTION}

The Turbinellidae is one of the most ancient of neogastropod families, contains five recent subfamilies, the Turbinellinae, Vasinae, Columbariinae, Ptychatractinae and Tudiclinae (Ponder \& Warén, 1988). The shell of subfamily Columbariinae, known as Pagoda shells, are mostly strongly keeled at the shoulder, delicately sculptured, and have a long, straight siphonal canal like that of Fusinus. The Columbariinae, is contains about 50 species in 6 genera, the best known of which is Columbarium. They are found especially in the New Zealand and Australian region. The Turbinellidae shell was reported from Korea for the first time and collected a depth of approximately 30 $\mathrm{m}$ by fishing nets in the port of Dadaepo.

\section{SYSTEMATICS ACCOUNTS}

Class Gastropoda Cuvier, 1797 복족강

Order Sorbeoconcha Ponder \& Lindberg, 1997 흡강목

Family Turbinellidae Swainson, 1835 잣송이고둥과

Received January 7, 2011; Revised January 31, 2011; Accepted March 3, 2011

Corresponding author: Jun-Sang Lee

Tel: +82 (61) 659-3166 e-mail: sljun@kangwon.ac.kr $1225-3480 / 24378$
Genus Columbarium Martens, 1881 잣송이고동속 (신 칭)

* Columbarium pagoda pagoda (Lesson, 1834 in 1832-35) 잣송이탑고둥 (신칭) (Fig. 1.)

Fusus pagoda Lesson, 1834, 12-14.

Columbarium pagoda pagoda Habe \& Okutani, 1975, p.103; Higo et al, 1993, p.274; Higo et al, 1999, p.223; Okutani et al, 2000, p. 423, pl. 210, 9; Wu \& Lee, 2005, p.163, fig. 690.

Columbarium pagoda Kira, 1977, p.59, pl.23, fig. 19; Okada et al, 1967, p.127

Type locality. Japan

Material examined. 7 individuals, Dadaepo, Saha-gu Busan Metropolitan City ( $35^{\circ} 3^{\prime} 30.75^{\prime \prime} \mathrm{N}, 128^{\circ} 58^{\prime}$ $57.33 " \mathrm{E}$, depth of $30 \mathrm{~m}$ by fishing net), 20 Oct. 2010.

Measurement. $80 \mathrm{~mm}$ in shell height; $26 \mathrm{~mm}$ in shell width.

Description. Shell moderate in size, $80 \mathrm{~mm}$ in height, $26 \mathrm{~mm}$ in width, solid, narrowly fusiform in out line and markedly longer than wide. 10 to 12 trigonal shoulder spines direct upward on body whorl, each spire. Protoconch is small, a bulbous and deflected of one and a half to two whorls, a columella without folds; spine or keel on the shoulder; and pronounced. Siphonal canal is open and long, and several strong columellar plaits. Opercular elongated 


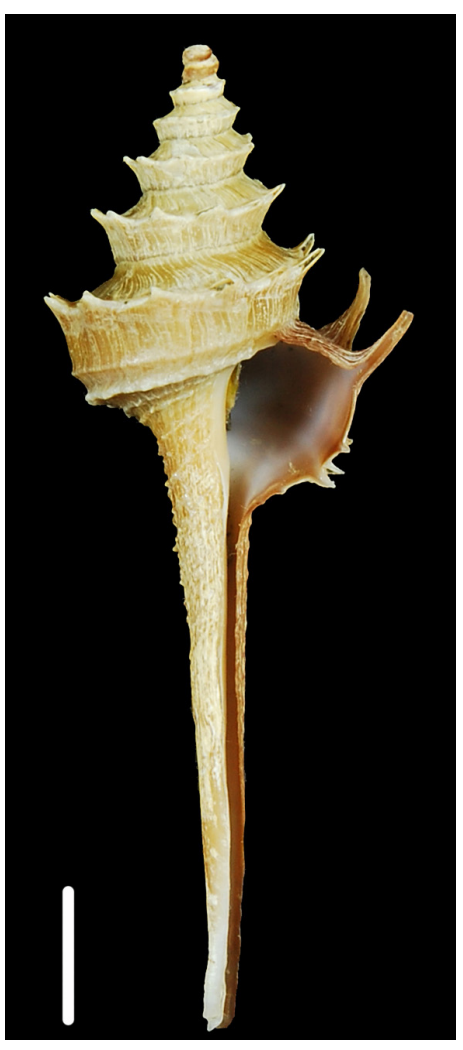

a

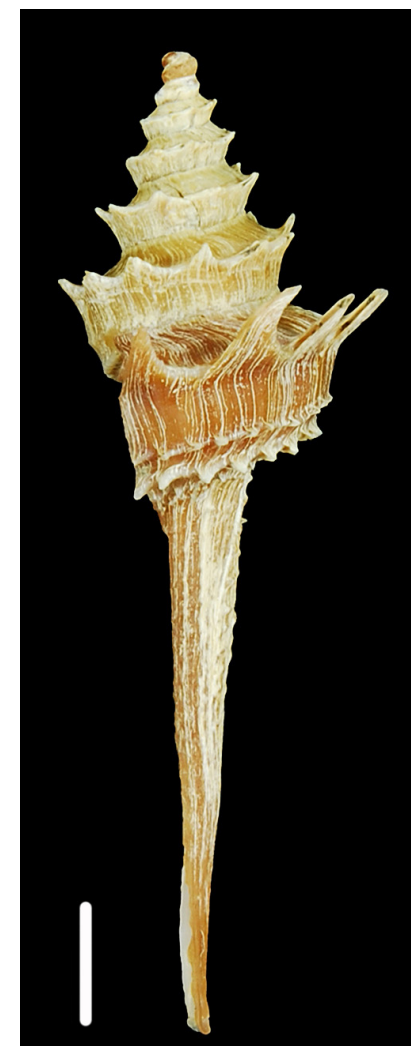

$\mathrm{b}$

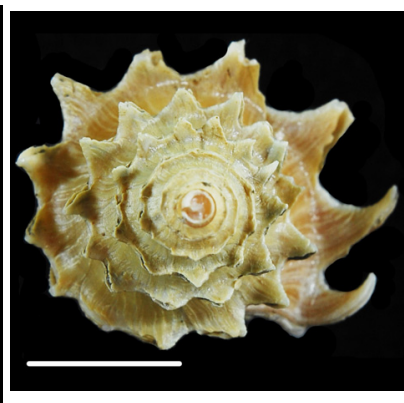

C

Fig. 1. Columbarium pagoda pagoda.: a, ventral view; b, later view; c, apical view. scale bar $=20 \mathrm{~mm}$.

with terminal nuclei, and often a thick periostracum.

Habitat. fine sand bottom in 20-300 m deep.

Distribution. East Sea, East China Sea.

Remark. The three Columbarium species reported in Japan, but C. pagoda pagoda is the only one species in Korean water.

\section{ACKNOWLEDGEMENTS}

This study was carried out as the project "The Discovery of Korean Indigenous Species" supported by the National Institute of Biological Resources (NIBR), Korea.

\section{REFERENCES}

Lesson, R.P. (1832-35). Illustrations de Zoologie, ou recueil de figures $d^{\prime}$ animaux peintes $d^{\prime}$ après nature. 60 plates with unnumbered text pages, issued in part:1-5 (1832);6-11(1833);12-14(1834); 15-20(1835). Pub. Arthus Betrand, Paris.

Habe, T. \& Okutani, T. (1975) Gakken Illustrated
Nature Encyclopedia the Mollusks of Japan. Vol. I, Gakken Co., Tokyo.

Higo, S. \& Goto, Y. (1993) A systematic list of mollusca shells from the Japanese Is. and adjacent area. pp.693, Yuko Pub. Co., Ltd., Osaka. [in Japanese]

Higo, S., Callomon, P. \& Goto, Y. (1999) Catalogue and Bibliography of the Marine Shell-Bearing Mollusca of Japan. pp.749, Elle Scientific Publication. Osaka.

Okutani, T.(Ed.) (2000) Marine Mollusks in Japan. pp. 1172, Tokai Univ. Press. Tokyo. [in Japanese and English]

Okada, K. (1967) New illustrated encyclopedia of the fauna of Japan (II). pp. 1-803, Hokuryukan Co., LTD, Tokyo.

Wu, W.L. \& Lee, Y. C. (2005) The Taiwan Common Mollusks in Color. Taiwan.

Kira, T. (1977) Colored illustrated of the shells of Japan. pp. 240, pls. 71. Hoikusha Pub. Co. Osaka. [in Japanese]

Ponder, W.F. \& Warén, A (1988) Classification of the Caenogastropoda and Heterogastropoda- a list of the family-group names and higher taxa pp. 288-328 in Ponder, W.F. (ed.) Prosobranch Phylogeny. Malacological Review, Supplement 4. 